\title{
New generation graphene-based dendritic phthalocyanine: Potential usage for biomedical applications
}

\section{Yeni üretim grafen-tabanlı dendritik ftalosiyanin: Biyomedikal uygulamalar için potansiyel kullanımı}

\author{
Ebru Yabaș
}

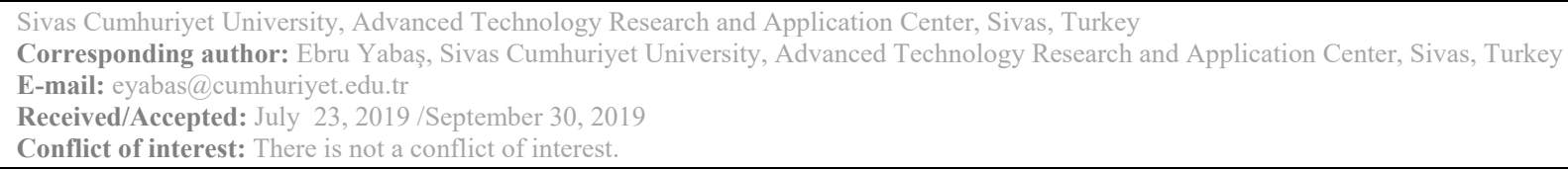

\section{SUMMARY}

Objective: It is aimed to produce new graphene-based materials with potential used in biomedical applications.

Method: The new GO-ZnPc hybrid was obtained by self-assembly method. Sonication was performed in the formation of hybrid. UV-Vis, emission spectra and scanning electron microscopy (SEM) were used to characterize ZnPc-GO hybrid formation.

Results: The GO solutions of different concentrations $(0.0005 \mu \mathrm{g} / \mathrm{mL}$; $0.005 \mu \mathrm{g} / \mathrm{mL} ; 0.05 \mu \mathrm{g} / \mathrm{mL} ; 0.4 \mu \mathrm{g} / \mathrm{mL} ; 0.7 \mu \mathrm{g} / \mathrm{mL} ; 1 \mu \mathrm{g} / \mathrm{mL}$ ) prepared by sonication were added to $10 \mu \mathrm{g} / \mathrm{mL} \mathrm{ZnPc}$ solution separately and sonicated again. UV-Vis, emission spectra and scanning electron microscopy (SEM) were used to characterize $\mathrm{ZnPc-GO}$ hybrid formation. All measurements showed that intermolecular interactions occurred after mixing the two components together, and the resulting hybrid was stable.

Conclusions: In this study, the new ZnPc-GO hybrid prepared and characterized. $\mathrm{ZnPc}$ and $\mathrm{GO}$ derivative was observed to well-coordinated. The obtained hybrid system was observed to have very interesting spectroscopic properties. It was observed that the GO-based $\mathrm{ZnPc}$ hybrid gave an absorption peak at $716 \mathrm{~nm}$ in the UV-Vis spectrum. The redshift observed with the ZnPc-GO hybrid formation in the UV spectra indicates that this material has the potential to be used in many biomedical applications, especially in tissue engineering and photodynamic therapy.

Keywords: Graphene oxide, phthalocyanine, dendrimer, biomedical applications
ORCID IDs of the authors: E.Y. 0000-0001-7163-3057

\section{ÖZET}

Amaç: Biyomedikal uygulamalarda kullanılan potansiyele sahip yeni grafen bazlı materyallerin üretilmesi amaçlanmaktadır.

Yöntem: Yeni GO-ZnPc hibridi self-assembly yöntemiyle elde edildi. Sonikasyon işlemi hibrit oluşumunda kullanıldı. ZnPc-GO hibrid oluşumunu karakterize etmek için UV-Vis, emisyon spektrumları ve taramalı elektron mikroskopisi (SEM) kullanılmıștır.

Bulgular: Sonikasyonla hazırlanan farklı konsantrasyonlardaki $(0.0005 \mu \mathrm{g} / \mathrm{mL} ; 0.005 \mu \mathrm{g} / \mathrm{mL} ; 0.05 \mu \mathrm{g} / \mathrm{mL} ; 0.4 \mu \mathrm{g}$ / $\mathrm{mL} ; 0.7 \mu \mathrm{g} / \mathrm{mL} ; 1 \mu \mathrm{g} / \mathrm{mL}$ ) GO çözeltileri $10 \mu \mathrm{g} / \mathrm{mL}$ derişimindeki ZnPc çözeltisine ayrı ayrı eklendi ve tekrar sonikasyon yapıldı. ZnPc-GO hibrid oluşumunu karakterize etmek için UV-Vis, emisyon spektrumları ve taramalı 
elektron mikroskopisi (SEM) kullanılmıștır. Tüm ölçümler, moleküller arası etkileșimlerin iki bileșenin birlikte karıștırılmasından sonra gerçekleștiğini ve sonuçta ortaya çıkan hibridin kararlı olduğunu gösterdi.

Sonuç: Bu çalışmada yeni ZnPc-GO hibrid hazırlandı ve karakterize edildi. ZnPc ve GO türevinin iyi koordine olduğu gözlendi. Elde edilen hibrit sistemin çok ilginç spektroskopik özelliklere sahip olduğu gözlendi. GO-bazlı ZnPc hibridin UV-Vis spektrumunda $716 \mathrm{~nm}$ 'de absorpsiyon piki verdiği gözlendi. UV spektrumunda ZnPc-GO hibrid formasyonu ile gözlemlenen kırmızı kayma, bu malzemenin, özellikle doku mühendisliği ve fotodinamik terapide, birçok biyomedikal uygulamada kullanılma potansiyeline sahip olduğunu göstermektedir.

Anahtar sözcükler: Grafen oksit, ftalosiyanin, dendrimer, biyomedikal uygulamalar

\section{INTRODUCTION}

Graphene is nanomaterial that a single layer, 2dimensional structure. Graphene and graphene derivatives have a high surface area, excellent electrical conductivity, strong mechanical strength, unparalleled thermal conductivity and remarkable biocompatibility ${ }^{1}$. Graphene-based materials have the ability to adsorb various aromatic biomolecules through $\pi-\pi$ stacking interaction and/or electrostatic interaction, making these compounds ideal materials for the fields of biosensors, drug delivery systems, and drug active substances. On the other hand, the hydrophobic nature of graphene prevents its use in the biomedical field. Graphene derivatives such as graphene oxide (GO) and reduced graphene oxide (RGO) have been extensively studied for various biomedical applications. GO with multiple oxygen-containing groups on graphene can be easily replaced with targeting ligands to facilitate targeted imaging and drug delivery ${ }^{1,2}$. GO-based materials have the potential to be used in pharmaceutical carrier systems, biosensor applications, photodynamic therapy and bio-imaging ${ }^{2}$. According to the literature, the use of GO-based materials is frequently seen in cancer treatment and photodynamic therapy applications ${ }^{3-10}$. Phthalocyanines have the potential to be used in many areas of advanced technology due to their interesting physical, chemical properties and stability. Phthalocyanines have also potential to be used especially in photodynamic therapy. There are many studies in the literature regarding the potential of phthalocyanine species to be used in the fields of photodynamic therapy ${ }^{11,12}$ and different biomedical areas ${ }^{13-15}$. The superior properties of phthalocyanines, especially red- shifted Q bands in the UV spectrum, provide the potential for use in photodynamic therapy and photodynamic diagnosis ${ }^{13}$. Dendrimers are regularly branched structures with threedimensional architecture. These structures with functional components located on the outer surface have interesting physical and chemical behavior and have the potential to be used in biomedical fields ${ }^{13,16-19}$. It is expected that the new materials to be obtained by combining these species, which are highly active in medical applications, will have more interesting properties.

\section{MATERIAL AND METHODS}

The dendritic zinc(II) phthalocyanine ( $\mathrm{ZnPc}$ ) was prepared according to the literature (Figure 1$)^{20}$. DMSO, used as a solvent, is of spectroscopic purity. UV-vis spectra were recorded on a Shimadzu UV-1800 UV-vis spectrophotometer. An Agilent/Cary Eclipse G9800A fluorescence spectrophotometer was used for spectrofluorometric measurements. SEM images were taken at Tescan MIRA3 XMU. SONICS Vibra-Cell CVX750 sonicator was used for sonication. Graphene oxide and graphene oxidephthalocyanine hybrid solutions were prepared at 700 Watt in sonicator.

\section{Synthesis of graphene oxide-dendritic zinc(II) phthalocyanine hybrid}

GO solutions at different concentrations $(0.0005$ $\mu \mathrm{g} / \mathrm{mL} ; 0.005 \mu \mathrm{g} / \mathrm{mL} ; 0.05 \mu \mathrm{g} / \mathrm{mL} ; 0.4 \mu \mathrm{g} / \mathrm{mL}$; $0.7 \mu \mathrm{g} / \mathrm{mL} ; 1 \mu \mathrm{g} / \mathrm{mL}$ ) were prepared in DMSO by sonication. The solution of $10 \mu \mathrm{g} / \mathrm{mL}$ of phthalocyanine in DMSO was added to these solutions, respectively. The prepared solutions were sonicated for 10 minutes. 


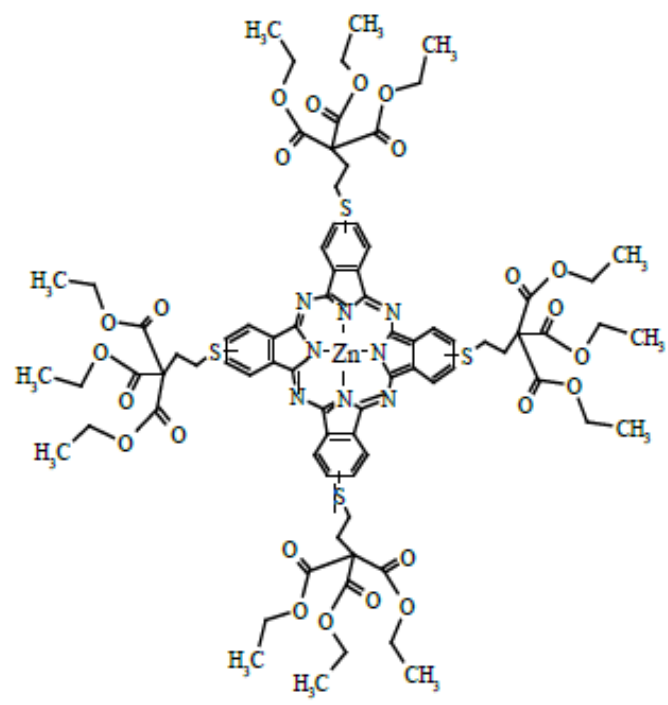

Figure 1: Molecular structure of $\mathrm{ZnPc}{ }^{20}$.

\section{RESULTS}

UV-Vis, emission spectra and scanning electron microscopy (SEM) were used to characterize $\mathrm{ZnPc}-\mathrm{GO}$ hybrid formation.

The GO solutions of different concentrations $(0.0005 \mu \mathrm{g} / \mathrm{mL} ; 0.005 \mu \mathrm{g} / \mathrm{mL} ; 0.05 \mu \mathrm{g} / \mathrm{mL} ; 0.4$

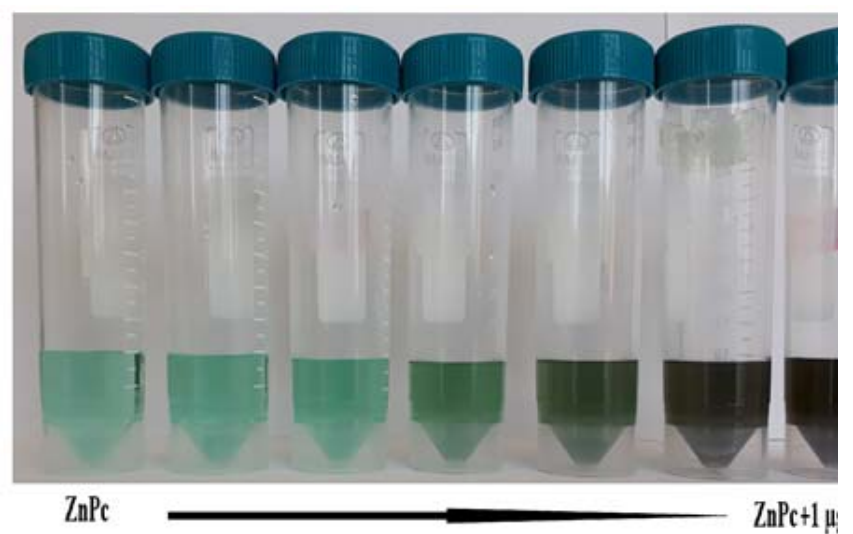

Figure 2: The color change of $\mathrm{ZnPc}-\mathrm{GO}$ hybrids at different concentrations (GO concentration increases from left to right). $\mu \mathrm{g} / \mathrm{mL} ; 0.7 \mu \mathrm{g} / \mathrm{mL} ; 1 \mu \mathrm{g} / \mathrm{mL}$ ) prepared by sonication were added to $10 \mu \mathrm{g} / \mathrm{mL} \mathrm{ZnPc}$ solution separately and sonicated again. The color changes of GO-ZnPc hybrids at different concentrations are shown in Figure 2. As can be seen from Figure 1, the color of the solutions changes significantly with the change in GO concentration.

$\mathrm{UV}-\mathrm{V}$ is spectra were examined after the interaction of GO solutions of different concentrations with $\mathrm{ZnPc}$. ZnPc-GO hybrid formation was observed in the UV spectra by the changes in the characteristic Q-band for phthalocyanines. As shown in Figure 3, it was observed that binding was completed by the interaction of $\mathrm{ZnPc}$ at $10 \mu \mathrm{g} / \mathrm{mL}$ and GO at $1 \mu \mathrm{g} /$ $\mathrm{mL}$. In the UV-Vis spectra, the addition of GO at different concentrations on $\mathrm{ZnPc}$ showed that the peaks gradually became flattened and a new peak formed. In addition, a redshift of $28 \mathrm{~nm}$ was observed in the spectrum. This shift is a significant value. It is seen that $\mathrm{ZnPc}$ and GO species are wellcoordinated, especially $\pi-\pi$ interactions due to conjugated structures. 


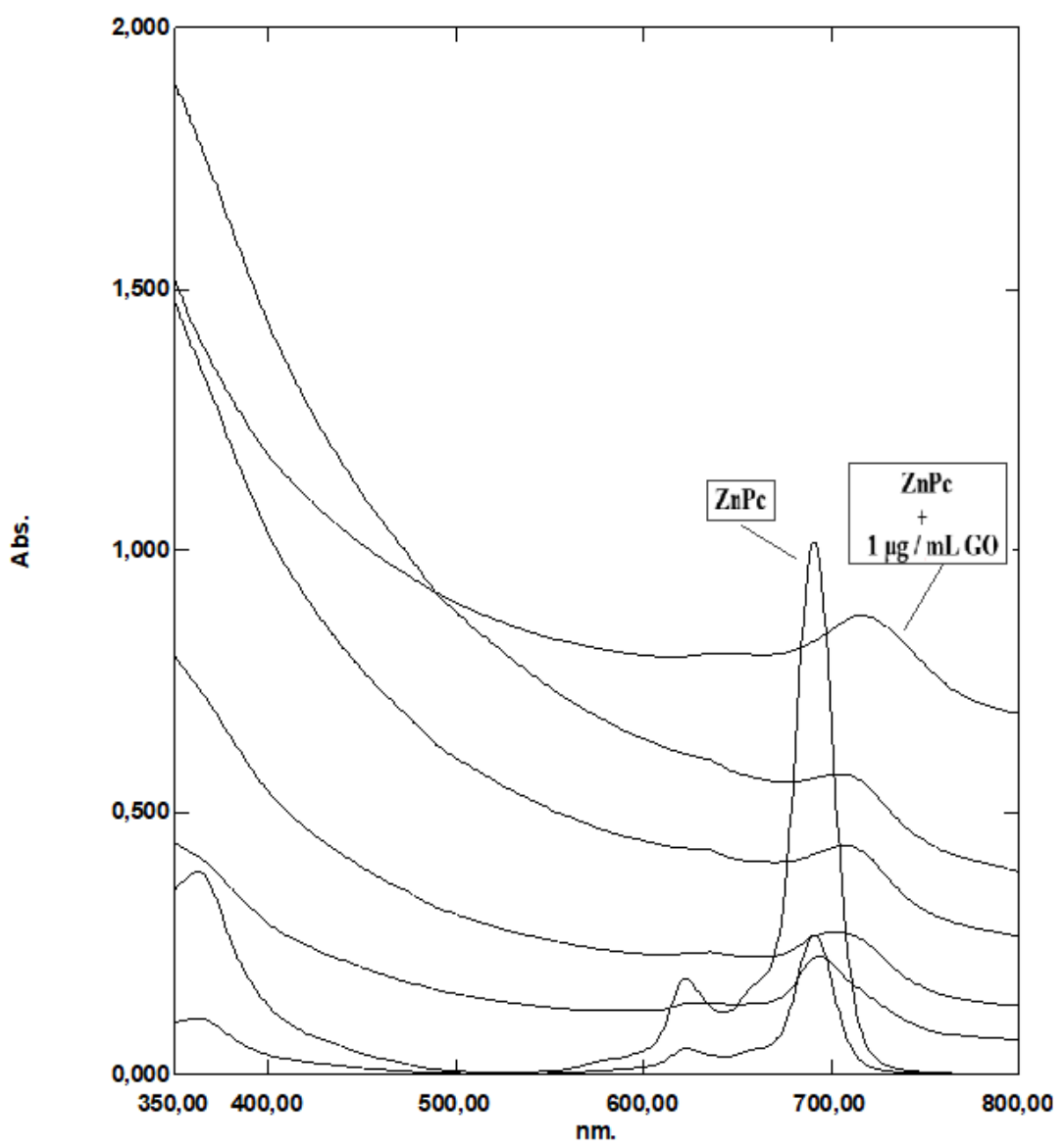

Figure 3: UV-Vis spectra depending on graphene oxide of different concentrations of ZnPc-GO hybrid (GO concentrations: $0.0005 \mu \mathrm{g} / \mathrm{mL} ; 0.005 \mu \mathrm{g} / \mathrm{mL} ; 0.05 \mu \mathrm{g} / \mathrm{mL} ; 0.4 \mu \mathrm{g} / \mathrm{mL} ; 0.7 \mu \mathrm{g} / \mathrm{mL} ; 1 \mu \mathrm{g} / \mathrm{mL}$ ).

Emission spectra were examined after the interaction of $\mathrm{GO}$ solutions of different concentrations with $\mathrm{ZnPc}$ for $\mathrm{ZnPc}-\mathrm{GO}$ hybrid formation. As shown in Figure 4, it was observed that binding was completed by the interaction of $\mathrm{ZnPc}$ at $10 \mu \mathrm{g} / \mathrm{mL}$ and $\mathrm{GO}$ at $1 \mu \mathrm{g} / \mathrm{mL}$. Significant changes in peaks were observed with the addition of GO at different concentrations on $\mathrm{ZnPc}$ in the emission spectra. These changes support the formation of the ZnPc-GO hybrid structure. It is observed that the formation of the ZnPc-GO hybrid significantly decreases in the area below the $\mathrm{ZnPc}$ emission peak.

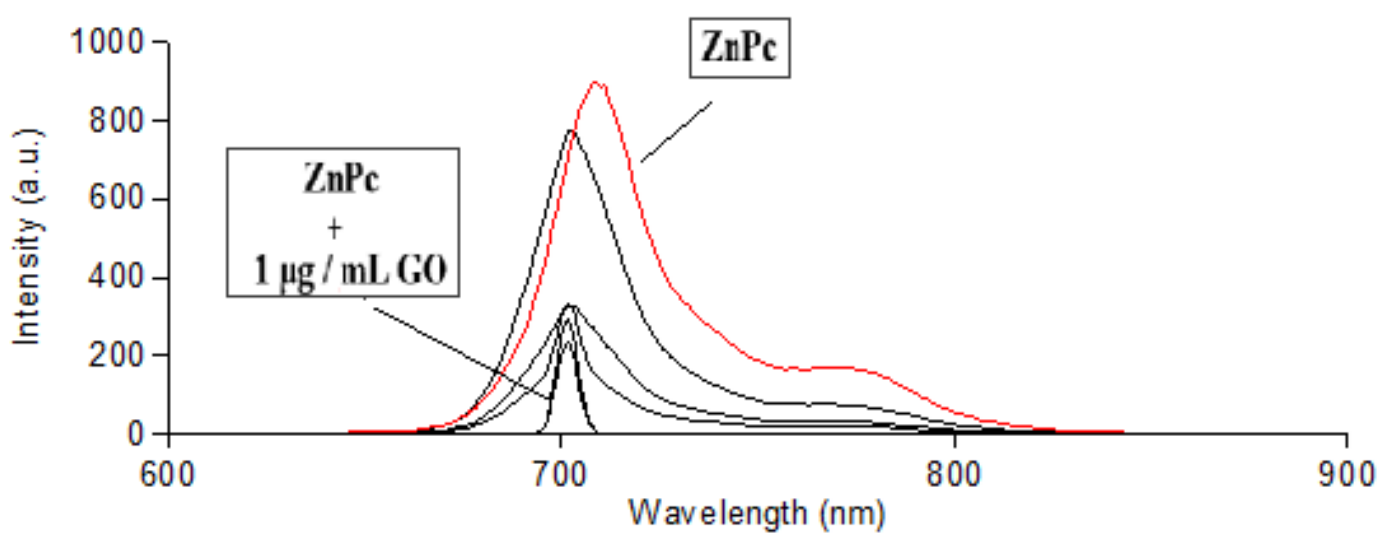

Figure 4: Emission spectra depending on graphene oxide of different concentrations of ZnPc-GO hybrid (GO concentrations: $0.0005 \mu \mathrm{g} / \mathrm{mL} ; 0.005 \mu \mathrm{g} / \mathrm{mL} ; 0.05 \mu \mathrm{g} / \mathrm{mL} ; 0.4 \mu \mathrm{g} / \mathrm{mL} ; 1 \mu \mathrm{g} / \mathrm{mL}$ ) 
The effect of sonication time on hybrid formation was also investigated. $0.4 \mu \mathrm{g} / \mathrm{mL}$ GO solutions were separately added to the $\mathrm{ZnPc}$ solutions and sonicated for 1,5 and 10 minutes. UV-Vis and emission spectra of these solutions were examined. As shown in Figure 5, the $\mathrm{ZnPc}-\mathrm{GO}$ hybrid formation was observed to be complete in 10 minutes. The sonication time for the new $\mathrm{ZnPc}-\mathrm{GO}$ hybrid was optimized to 10 minutes. Sonication time also has a significant effect on hybrid formation.

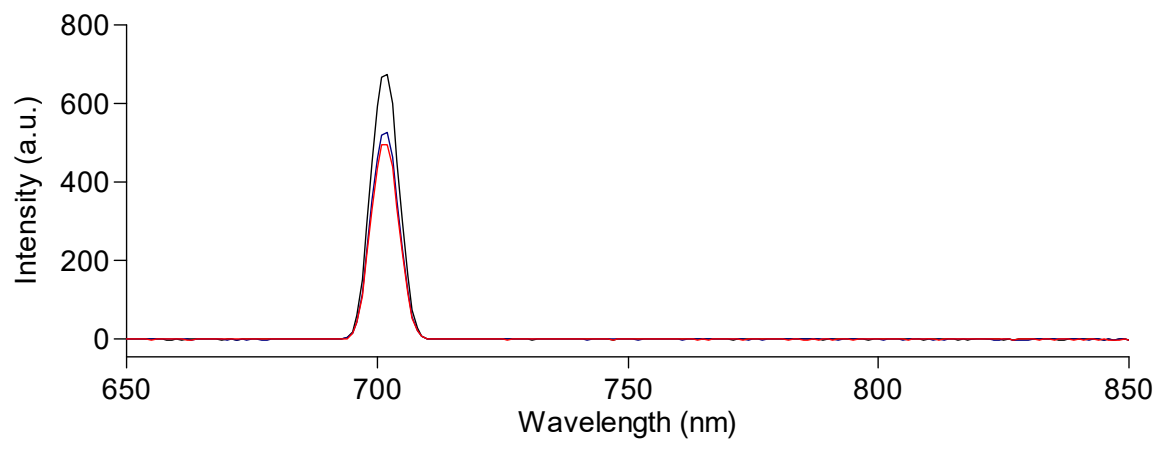

Figure 5: Emission spectra depending on sonication time of ZnPc-GO hybrid (1.min 5.min 10.min, (from top to bottom, respectively))

It is also seen from the SEM images that the binding of $\mathrm{ZnPc}$ increases as the concentration of $\mathrm{GO}$ increases (Figure 6). Figure 6 shows concentrations of $\mathrm{GO}$ in $\mathrm{ZnPc}$ as $0.005 \mu \mathrm{g} / \mathrm{mL}$ and $1 \mu \mathrm{g} / \mathrm{mL}$ GO. Increasing GO concentration increases the bridge formation and GO interlayer filling by $\mathrm{ZnPc}$. The polymer chain branching

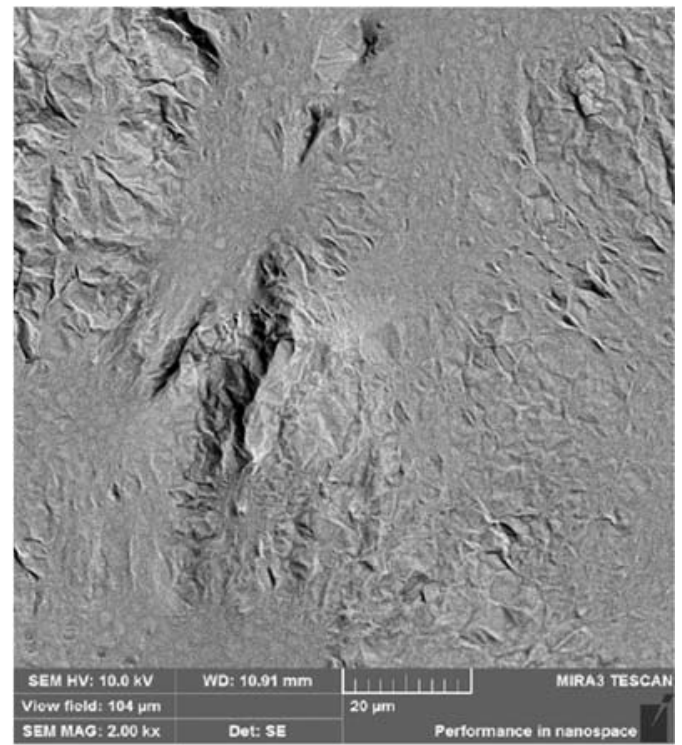

$\mathrm{ZnPc}+0,0005 \mu \mathrm{g} / \mathrm{mL}$ GO contiguity is obtained by increased concentration of GO by layered structure. The concentration of GO was adjusted to $1 \mu \mathrm{g} / \mathrm{mL}$ in $\mathrm{ZnPc}$ solution in DMSO and the structure is seen as GO of few-layer structures and combined to each other by increased concentration.

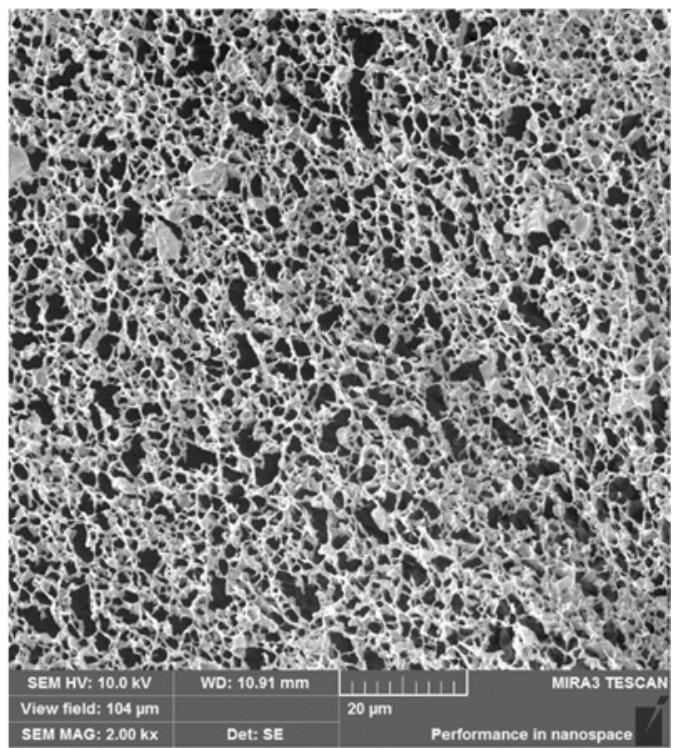

$\mathrm{ZnPc}+1 \mu \mathrm{g} / \mathrm{mL}$ GO

Figure 6: SEM images of ZnPc-GO hybrids 


\section{DISCUSSION}

The new GO-ZnPc hybrid was obtained by selfassembly method. Sonication was performed in the formation of hybrid. The effect of dilution on hybrid formation was investigated by absorption and fluorescence spectra. The effect of sonication on hybrid formation was also investigated by absorption and emission spectra. The sonication time also contributed to the formation of $\mathrm{ZnPc}-\mathrm{GO}$ hybrid system. The formation of the obtained hybrids was also characterized by scanning electron microscopy (SEM).

By the formation of the $\mathrm{ZnPc}-\mathrm{GO}$ hybrid, a redshift of $28 \mathrm{~nm}$ from the characteristic Q-band of $\mathrm{ZnPc}$ was observed in the UV spectrum. This change in the UV spectrum indicates that the $\mathrm{ZnPc}$ and GO species are well coordinated. The absorption of ZnPc-GO hybrid materials increases the potential of being used in many biomedical applications. The interaction between $\mathrm{ZnPc}$ and $\mathrm{GO}$ is thought to be $\pi-\pi$ interactions due to its conjugated structures.

Significant changes were observed in the emission spectrum of the ZnPc-GO hybrid. The emission spectra also confirm the formation of the structure.

In the SEM images of the ZnPc-GO hybrid at different concentrations, it is observed that binding increases with increasing GO concentration. The SEM image on the right in figure 6 represents the fiber-like formation of GO-ZnPc composites. This composite formation can be a good candidate for both tissue engineering and UV sensitive polymers. Furthermore, the ZnPc-GO hybrid has the potential to be used as targeted drug delivery systems in photodynamic therapy as described in the literature 21,22 .

All measurements showed that intermolecular interactions occurred after mixing the two components together, and the resulting hybrid was stable.

\section{CONCLUSION}

In this study, the new ZnPc-GO hybrid prepared and characterized. $\mathrm{ZnPc}$ and $\mathrm{GO}$ derivative was observed to well-coordinated. The obtained hybrid system was observed to have very interesting spectroscopic properties. It was observed that the GO-based ZnPc hybrid gave an absorption peak at $716 \mathrm{~nm}$ in the UV-Vis spectrum. The redshift observed with the $\mathrm{ZnPc}-\mathrm{GO}$ hybrid formation in the UV spectra indicates that this material has the potential to be used in many biomedical applications, especially in tissue engineering and photodynamic therapy.

\section{Acknowledgments}

In this study, the laboratory facilities of the Advanced Technology Application and Research Center (CÜTAM) of Sivas Cumhuriyet University were used.

\section{REFERENCES}

1. Yang Y, Asiri A M, Tang Z, Du D, Lin Y. Graphene based materials for biomedical applications. Mater Today 2013; 16: 365-373.

2. Nanda S S, Papaefthymiou G C, Yi D K. Functionalization of Graphene Oxide and its Biomedical Applications. Crit Rev Solid State 2015; 40: 291-315.

3. Huang P, Xu C, Lin J, Wang C, Wang X, Zhang C, Zhou X, Guo S, Cui D. Folic Acid-conjugated Graphene Oxide loaded with Photosensitizers for Targeting Photodynamic Therapy. Theranostics 2011; 1: 240-250.

4. Li Y, Dong H, Li Y, Shi D. Graphene-based nanovehicles for photodynamic medical therapy. Int J Nanomed 2015; 10: 2451-2459.

5. Zhou L, Zhou L, Wei S, Ge X, Zhou J, Jiang H, Li F, Shen J. Combination of chemotherapy and photodynamic therapy using graphene oxide as drug delivery system. J Photoch Photobio B 2014; 135: 7-16.

6. Shen H, Zhang L, Liu M, Zhang Z. Biomedical Applications of Graphene. Theranostics 2012; 2: 283-294.

7. Youssef Z, Vanderesse R, Colombeau L, Baros $\mathrm{F}$, Roques-Carmes $\mathrm{T}$, Frochot $\mathrm{C}$, Wahab $\mathrm{H}$, Toufaily J, Hamieh T, Acherar S, Gazzali A M. The application of titanium dioxide, zinc oxide, fullerene, and graphene nanoparticles in photodynamic therapy. Cancer Nano 2017; 8: 1-62.

8. Tabisha $\mathrm{T}$ A, Zhanga S, Winyard $\mathrm{P}$ G. Developing the next generation of graphene-based platforms for cancer therapeutics: The potential role of reactive oxygen species. Redox Biol 2018; 15: 34-40.

9. Krajczewski J, Ruci'nska K, Townley H E, Kudelski A. Role of various nanoparticles in photodynamic therapy and detection methods of singlet oxygen. Photodiag Photodyn Therapy 2019; 26: 162-178.

10. Nene L C, Managa M, Nyokong T. Photophysicochemical properties and in vitro photodynamic therapy activity of morpholinesubstituted Zinc(II)-Phthalocyanines $\pi$ - $\pi$ stacked on biotinylated graphene quantum dots. Dyes Pigments 2019; 165: 488-498. 
11.Jinling H, Naisheng C, Jiandong H, Ersheng L, Jinping X, Suling Y, Ziqiang H, Jiancheng S. Metal phthalocyanine as photosensitizer for photodynamic therapy (PDT). Sci In China (Series B) 2001; 44: 113-122.

12.Lukyanets E A. Phthalocyanines as Photosensitizers in the Photodynamic Therapy of Cancer. J Porph Phthalocya 1999; 3: 424-432.

13.Figueiraa F, Pereiraa $P$ M R, Silvaa $S$, Cavaleiroa J AS, Tomé J P C, Porphyrins and Phthalocyanines Decorated with Dendrimers: Synthesis and Biomedical Applications. Curr Org Synth 2014; 11: 110-126.

14.Mody T D. Pharmaceutical development and medical applications of porphyrin-type macrocycles. J Porph Phthalocya 2000; 4: 362-367.

15.Li X, Zheng B D, Peng X H, Li S Z, Ying J W, Zhao Y, Huang J D, Yoon J. Phthalocyanines as medicinal photosensitizers: Developments in the lastfive years. Coord. Chem. Rev 2019; 379: 147160.

16.Boas U, Heegaard P M H. Dendrimers in drug research. Chem Soc Rev 2004, 33(1), 43-63.
17.Medina S H, El-Sayed M E H. Dendrimers as carriers for delivery of chemotherapeutic agents. Chem Rev 2009; 109(7): 3141-3157.

18.Tekade R K, Kumar P V, Jain N K. Dendrimers in oncology: an expanding horizon. Chem Rev 2010; 110(4): 2574-2574.

19.Jeong Y H, Yoon H J, Jang W D. Dendrimer porphyrin-based self-assembled nano-devices for biomedical applications. Polymer J 2012; 44: 512521.

20.Yabaş E, Sülü M, Özgür A, Tutar Y. Effect of New Water-Soluble Dendritic Phthalocyanines on Human Colorectal and Liver Cancer Cell Lines. Süleyman Demirel University J Natur Appl Sci 2017; 21: 689-695.

21.Zhou L, Zhou L, Wei S, Ge X, Zhou J, Jiang H, Li F, Shen J. Combination of chemotherapy and photodynamic therapy using graphene oxide as drug delivery system. J Photochem Photobiol B 2014; 135: 7-16.

22.Huang P, Xu C, Lin J, Wang C, Wang X, Zhang C, Zhou X, Guo S, Cui D. Folic Acid-conjugated Graphene Oxide loaded with Photosensitizers for Targeting Photodynamic Therapy. Theranostics 2011; 1: 240-250. 